\title{
Budget transparency innovation in the Czech local government
}

\begin{abstract}
Budget transparency innovations bring new extent and forms of transparency. The aim of the article is to explore the diffusion of budget explorers, that is, a budget transparency innovation extremely popular in the Czech Republic, and to evaluate their impact on voluntary budget information disclosed.

Careful mapping of the diffusion using a survey of budget explores in 72 former Czech district towns and media analysis shows that the key success factor was its convenience for politicians, as it is attractive, easy to implement and up-to-date demonstration of their transparency. Budget explorers are nowadays a standard extension to accounting software, and their usage is evaluated in several government transparency competitions.

The major benefit of the budget explorers is that they made for the first time publicly available detailed public financial information, changed the standard of best practice and drew some public attention. At the same time, they, unfortunately, narrowed the scope of the budget transparency debate by omitting the importance of the draft budget and introduction of performance measurement.
\end{abstract}

KEYWORDS: transparency innovation, budget explorer, budget transparency, local government

JEL CLASSIFICATION: H72, O31

RECEIVED 16 November 2018; ACCEPTED 14 March 2019.

\section{INTRODUCTION}

Fast development of information and communication technologies (ICT) enabled extent and forms of transparency that were impossible in the pre-computer age (Bannister and Connolly, 2011). It also significantly lowered the costs of collecting, distributing and accessing government information (Bertot, Jaeger and Grimes, 2010).

Transparency, in general, means citizens' access to government information and information about government and facilitating citizens understanding of government functioning (Bannister and Connolly, 2011), and it ultimately serves to keep government honest (Bertot, Jaeger and Grimes, 2010). Transparency is considered an essential democratic value that ensures a trustworthy, high performing and accountable government either directly (Grimmelikhuijsen and Welsch, 2012) or as a prerequisite of these characteristics of good governance (e.g. Bovens, 2007; Heald, 2012; or Halachmi and Greiling, 2013). The relationship between transparency and good governance is, however, often not straightforward (Szabo et al., 2016).

Budget transparency focuses on government management and macro and micro level dimensions of the revenue and expenditure sides of public budgets, and it is a mean of improving economic governance (Heald, 2003). Budget transparency reduces fiscal illusion, that is, a situation when the public does not recognise the total tax burden (tax illusion) or full costs of government borrowing (debt illusion) and believes that the benefits of public expenditure are higher than the real tax price (expenditure illusion) (Fasora, 2012). One of the causes of fiscal illusion can be lack of attention (Baekgaard, Serritzlew and Blom凶Hansen, 2016). At the same time, budget transparency enables voters to understand better the budget and increases politicians' commitment to be fiscally responsible (Benito and Bastida, 2009).

Budget transparency is usually defined as a full disclosure of all relevant fiscal information in a timely and systematic manner (OECD, 2002). In an operationalised way provided by the Open Budget Partnership (2017), budget transparency is the amount, level of detail and timeliness of budget information governments make publicly available through the whole budget cycle, and the 
Open Budget Survey may serve as a detailed checklist of required data and documents. In contrary, the Fiscal Transparency Code (IMF, 2017) sets an international standard for the disclosure of information about public finances with the aim to guarantee the comprehensiveness, clarity, reliability, timeliness and relevance of public reporting on the past, present and future state of public finances. Efforts of the IMF clearly show that budget transparency is not only directed outside of the government, for example, citizens, but also inside - how could the executive manage public finances if it was not aware of its exact extent because of, for example, extra-budgetary operations or tax expenditures?

Information disclosure does not equal budget transparency. Heald (2003) regards the role of government in ensuring that all relevant information is available to all actors but added that transparency requires an audience with the capacity to understand and act (Heald, 2012). Government officials often think that they give precise information on the budget and budget management but are puzzled by citizens' responses (Rubin, 2000). Full disclosure of all relevant fiscal information does not necessarily mean that citizens know if they are getting a good deal for their money (Rubin, 1996). The pure availability of budget documents is thus accompanied by the requirement of their accessibility to the public (Ramkumar and Shapiro, 2011) because transparency does not happen by itself as 'budgets do not wade into crowds and draw around them circles of admiring readers' (Rubin, 2000, p. 9). So it is necessary to find new ways of budget information provision that make the general public more interested in it and that enable its understanding (Rubin, 1996). The utilisation of ICT directly offers itself for this task.

The article aims to explore the diffusion of budget explorers and evaluate their impact on voluntary budget information disclosed. It presents a case study of a specific ICT-driven budget transparency innovation that gained extreme popularity in the Czech Republic over the past decade - budget explorers, literarily 'click-through budgets'.

Budget explorers or public's checkbooks are various software platforms presenting public budgets and their execution. They allow interactive multidimensional data analysis with flexible and user-friendly dynamic query and reporting options and visualisations (Dener and Min, 2013). They make, for the first time, publicly available granular budget data that can be further used and analysed. This is a substantial change when compared to the standard budget reports that only present aggregated budget tables.

The uniqueness of the Czech experience is shown through careful mapping of the diffusion of the new expression using the corpora and the actual launch of the tool in Czech towns. The evaluation of the expectations and key diffusion driving factors is based on substantial text analysis using the corpora to some extent as well. The assessment of the impact on transparency is based on a comparison of budget data provided by the budget explorers and other currently available information sources.

\section{Data and methods}

In the first phase of the research, we performed Internet search amongst the 72 former Czech district towns and located 45 budget explorers. We collected a set of characteristics describing each of the budget explorers, which included the period covered, budget phases and timeliness of presented data, type of classification and level of detail used, available visualisations and the software supplier. The data collection took place between 29 March and 17 May 2017. The data analysis was performed using descriptive statistics and pivot tables.

The characteristics of the budget explorers were compared to a nationwide budget explorer Monitor provided by the Ministry of Finance (2017) and to features of obligatorily published budget documents. Monitor provides, amongst other, municipal budget data since the fiscal year 1997. It includes approved, amended and executed budget using the national budget classification. Data are updated quarterly with about 3 months' delay. Evaluation of the published budget documents is based on previous research (Sedmihradská, 2015a; Sedmihradská and Kučera, 2016).

In the second phase of the research, we compiled a media news collection dealing with budget explorers provided by the Czech media database ANOPRESS IT and on the Internet. This collection allowed us to map the origins and the spread of the concept of budget explorers and to construct a timeline of budget explorer launch in the analysed towns. Here we also used the press releases or information provided by the towns on their respective web pages.

To map the usage of the expression 'click-through budget', we used the Corpora of contemporary written Czech SYN release 5 provided by the Czech National Corpus. This was possible, thanks to the uniqueness of the Czech term used for budget explorers. The SYN corpora contents the reference corpus of newspapers and magazines between 1989 and 2015 (Hnátková et al., 2014). We used the tool KonText to analyse the frequency of usage of the expression 'click-through budget' across time and text types and its 
collocations. The words 'klikaci' and 'rozklikávaci' (click through) were searched with the lemma filter 'rozpočet' (budget) within five tokens in both directions.

In the third phase, we performed text analysis aimed at keywords identification in the articles published in a leading professional monthly journal Moderní obec (Modern Municipality) with the aim to capture the perception of budget explorers in media. We used six articles that dealt explicitly with budget explorers (Ryšavý, 2012; Přech, 2013; Winter, 2013a, 2013b; Kratochvílová, 2014; Pikartová, 2014). The keywords were identified using the KWords tool provided by the Czech National Corpus and the SYN2015 corpora. The log likelihood method at the 0.001 significance level was used, and the percentage of types listed as keywords was $5 \%$.

\section{Origins and fast spread of budget explorers}

The history of budget explores is very brief and well documented in media: The Czech term for the budget explorer - literally 'clickthrough budget' - was used in the media for the very first time in late 2010 with the explanation that it is a tool to finally understand public expenditure (Michl, 2010) and to know precisely how each tax-crown was spent (Michl, 2012).

Non-profit project Rozpočet veřejně (Budget publicly) launched a budget explorer for executed budgets of all 6,250 Czech municipalities in May 2011 (Rozpočet veřejně, 2011). It was the first well-functioning budget explorer in the Czech Republic. A

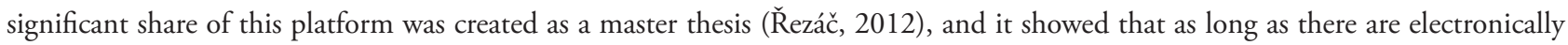
available uniform and detailed budget data, creation of such platform is feasible even as a low-budget project.

The first budget explorers provided by government agencies were launched at the Ministry of Finance, in the City of Prague and town Semily in 2011 (Brendlová, 2011), and their usage grows steadily ever since (Figure 2).

Ministry of Finance launched a complex budget explorer called Monitor in April 2013. The launch of the Monitor and especially its analytical part in December 2013 made all public budget and accounting data in detail given by the respective regulations publicly available for various types of audiences and ways of usage.

The new concept gained quickly substantial attention. This is demonstrated by the growing number of newspaper articles mentioning budget explorers (Figure 1). Analysis of the frequency of two expressions 'rozklikávací rozpočet' and 'klikací rozpočet', which are used as synonyms, showed that significant growth in the usage of the terms is associated with the actual launch of the explorers. Whilst the early usage was mostly in relation with the expected impact of the explorers on transparency, since 2013, most of the articles inform about upcoming or actual launch mostly in local governments. More than half of the articles were published in regional periodicals.

Our survey performed in 72 former Czech district towns in spring 2017 showed that the usage of budget explorers is high. A budget explorer was located in 45 towns, that is, $62.5 \%$. This finding is in line with the results of a survey amongst 165 municipalities with extended power ${ }^{1}$ participating in the Hospitable municipal office competition in 2017 (Ministry of Interior, 2017). The number of district towns using a budget explorer grows steadily since 2013, and there is, on an average, a new town every month (Figure 2).

The text analysis showed that the innovators and many early adopters who inspired the others were smaller towns than the former district towns. Whilst there may be some positive impact of the electoral cycle on local government information disclosure (Cuadrado-Ballesteros et al., 2017), elections did not influence the budget explorers launch dates in the Czech district towns.

The diffusion of the budget explorers is quite even in the whole territory of the Czech Republic and does not show any regional pattern (Figure 3).

\section{Major diffusion sources}

On the basis of the media collection analysis and previous research (Sedmihradská, 2015b), we identified four factors that jointly contributed to the diffusion: (1) frequent promise of more transparent public management by politicians before an election, (2) high

1 Two hundred and five biggest Czech municipalities and 22 districts of the capital city Prague. 
Fig. 1: Number of articles dealing with budget explorers (2010-2015)

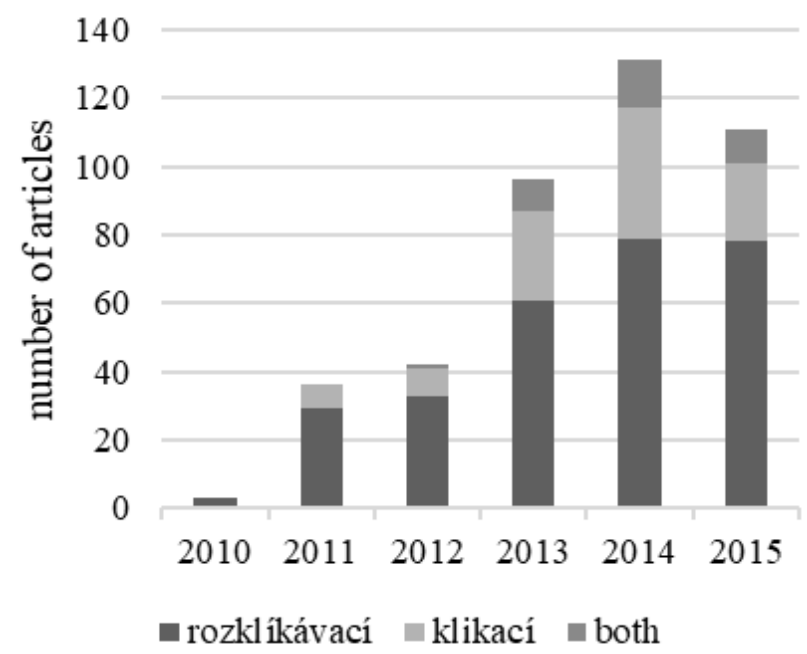

Source: Corpora of contemporary written Czech SYN release 5

Note: rozklikávaci and klikací are synonyms meaning 'click through'

Fig. 2: Number of towns using budget explorer by quarters of the years

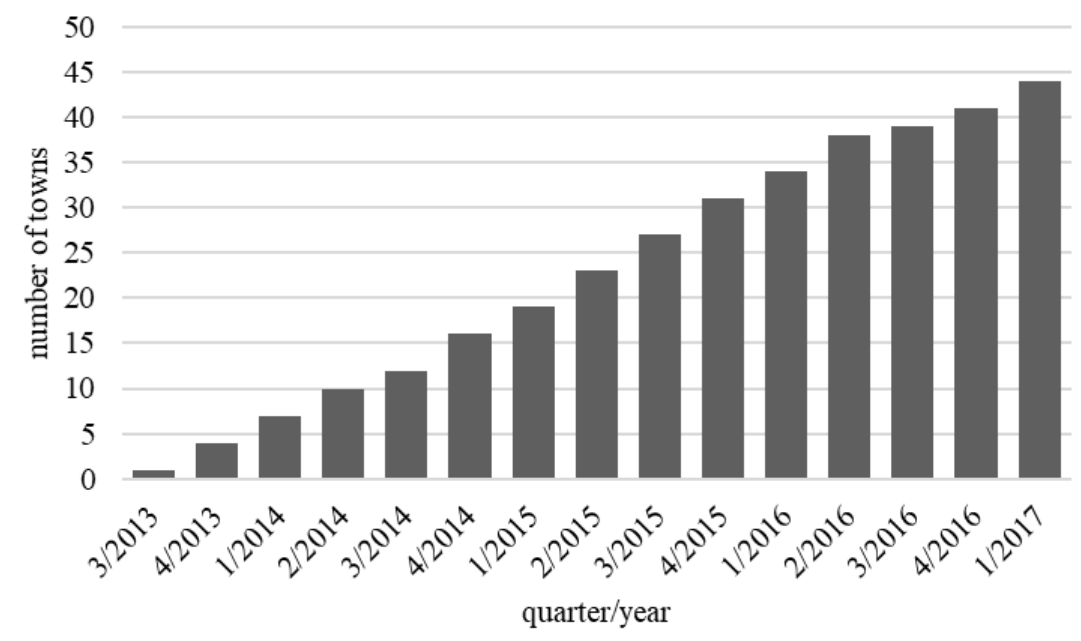

Source: Authors 


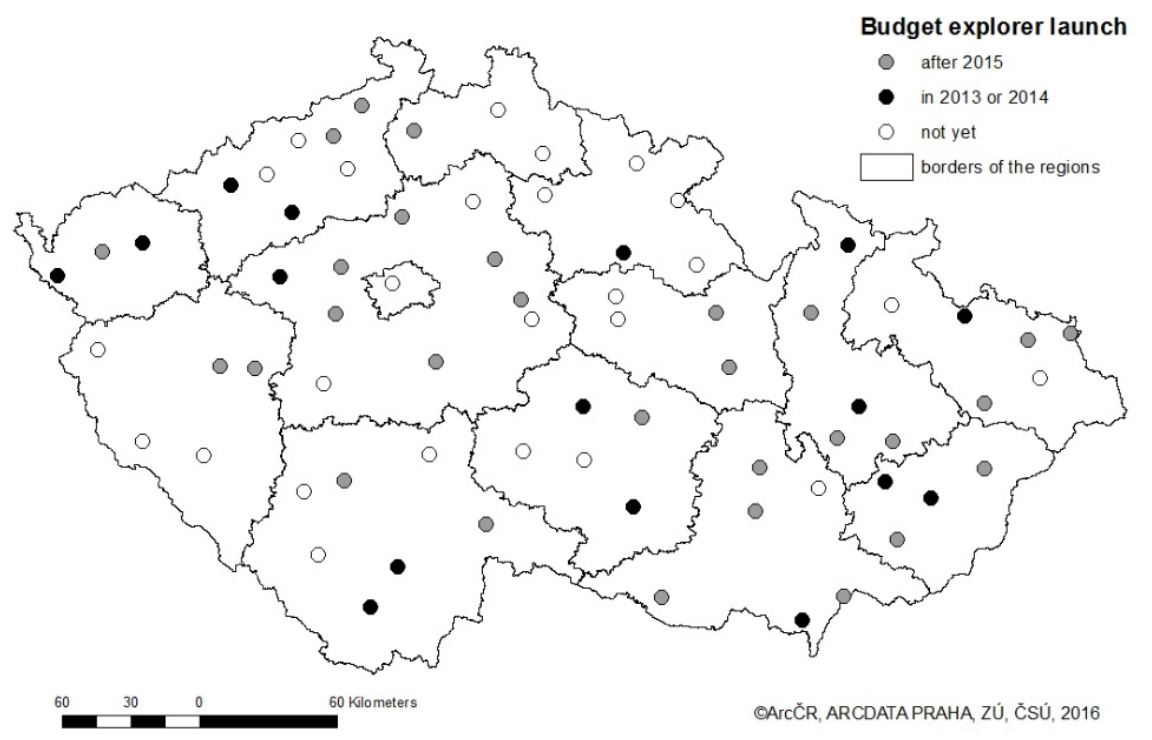

Source: Authors

public expectations, (3) active encouragement by several transparency competitions and evaluations and (4) varied supply of the respective software providers.

The key driver for fast and persisting diffusion of budget explorers is their convenience for local politicians who ultimately decide about their acquisition, as they are specific, visible, easy to realize and entirely up-to-date manifestation of their transparency.

The expectations of the impact of budget explorers were and still are incredibly high and, unfortunately, little realistic. This quote perfectly documents it: 'Citizens can, using their own eyes, get sure about economic and correct management' (Kratochvílová, 2014, p. 8).

Similar expectations are confirmed by the keywords identified in the six articles dealing with budget explores published in the professional journal Moderní obec between 2012 and 2014. They show that the major characteristic of budget explorer is a view or overview of detailed budget lines and disaggregated data and accounts. The key features are

- clear, transparent and public;

- individual and specific; and

- $\quad$ electronic and web based.

On the basis of the analysis of the concordance of the verbs around the keyword management, it is clear that budget explorers allow to track, control, describe or explain. So, generally, the reasoning is the following: very detailed data allow control and serve as description and explanation leading to understanding. The actual level of detail of the analysed budget explorers is evaluated in the next section of the article.

Competitions or ratings are useful policy tools to increase transparency and fight corruption (Sičáková-Beblabá, Beblavý, et al., 2008). In this particular case, their impact and further encouragement of the mimicking of the behaviour of others and general diffusion of budget explorers was quite palpable. Nové Město na Moravě started a real boom of budget explorers' implementation after it was awarded in a transparency competition Otevřeno x Zavřeno (Open x Close) and municipal web pages competition Zlatý erb (Golden coat of arms) in 2013 (Jakubcová and Paclík, 2013). These awards got significant media attention.

Competition Hospitable municipal office sponsored by the Ministry of Interior (2016 and 2017) and evaluation of the regions realised by Oživení (2016) use the availability of a budget explorer as one of the criteria for the evaluation of local governments 
transparency. All these competitions and evaluations set a standard of good practice and influence public expectations and perception of transparent behaviour and further motivate politicians to acquire it.

Providers of accounting software commonly offer the budget explorer platform as well (Přech, 2013). As soon as the technology has been developed, there are little technological problems for new adopters, as the software is an extension of the existing accounting system. At the same time, the costs are reasonable (Ševčíková, 2015). In Nový Jičín (2017) and Frýdek Místek (2017), the implementation costs were about 2,500 EUR and the annual operation costs were about 1,000 EUR. Our survey amongst the district towns showed that there are, at the moment, at least eight different providers of the budget explorers. Their number grew gradually from two in 2013 to four in 2014. Their products differ regarding both the data presentation and the available visualisations (Sedmihradská and Ždárský, 2017).

Feasible implementation, reasonable costs and perception of budget explorers as a new best practice pushed municipal politicians to provide their own budget explorers.

\section{Real added value to budget transparency}

Budget explorers may add value to budget transparency in several ways: amount, detail and timeliness of information provided; new ways of their possible utilisation; and the ability to draw attention and get new users of the provided fiscal information.

Local governments are subject to substantial mandatory budget disclosure requirements. They provide budget documents covering all phases of the budget cycle, that is, draft and approved budget, budget amendments, year-end report and multiannual budget outlook, on their web pages (Table 1).

At the same time, the Ministry of Finance (2017) provides a nationwide budget explorer, Monitor. It covers approved, amended and executed budget of all central agencies and all local governments since 1997 and accounting data for all public sector units since 2010. These data are updated quarterly. Since December 2013, the Monitor contains an analytical part that allows practically unlimited data upload through customised queries.

Comparison of the 45 budget explorers in the district towns and the Monitor revealed three areas in which municipal budget explorers provide additional information: (1) Approved budget for 2017 was available several months earlier, and information about its execution is updated more frequently. (2) There is available additional information in most of the towns at least in one of these areas: organisational classification of revenue and expenditure (58\%), information on individual investments over a multi-year period $(22 \%)$, programmes $(58 \%)$ or single invoices $(22 \%) .{ }^{2}$ (3) In case of statutory cities divided into independent districts, budget explorers provide information of the individual districts as well.

On the other hand, the municipal budget explorers rarely allow to download the data for further analysis and cover a shorter period. These are the significant advantages of the Monitor (Sedmihradská and Ždárský, 2017).

Budget documents are the only information source that covers the draft budget and multiannual budget outlook. Budget explorers and Monitor do not provide any information for the most important budget decision during the budget cycle - budget approval. This is, on one hand, self-evident as they are based on accounting/reporting data and these are not available during the preparation and debate of the budget; on the other hand, it severely limits the possible impact of this tool on the decision making.

Current legislation sets minimum standards regarding the obligatory budget documents, and it leaves enormous autonomy to individual municipalities regarding the content, detail and form of the documents. So, if politically desirable, any level of detail, as well as any file format, is possible. The variability of the documents and information provided is enormous (Sedmihradská, 2015a; Sedmihradská and Kučera, 2016). If a municipality wants to provide specific information, it is feasible to do so without a budget explorer. For some data, such as a list of suppliers or invoices, a spreadsheet format may be even more useful than the click-through form without a possibility to download the data.

The three information sources about municipal budget management complement each other, and if designed adequately, they may provide useful additional information. In our research, however, we were able to find both budget explorers and obligatory

2 The only town that provided all types of detailed information is Havlíčkův Brod. Its budget explorer is available at http://rozpocet.muhb.cz/cz/. 
Tab. 1: Amount and detail of budget information provided by the different information sources

\begin{tabular}{lllll}
\hline & & $\begin{array}{l}\text { Municipal budget } \\
\text { explorer }\end{array}$ & Monitor & Budget documents \\
\hline Detail according to national regulation & & $\mathrm{P}$ & $\mathrm{P}$ & $\mathrm{P}$ \\
\hline More detail & & $\mathrm{S}$ & $\mathrm{O}$ & $\mathrm{S}$ \\
\hline \multirow{2}{*}{$\begin{array}{l}\text { The phase of the } \\
\text { budget cycle }\end{array}$} & Draft budget & $\mathrm{O}$ & $\mathrm{P}$ & $\mathrm{P}$ \\
\cline { 2 - 5 } & Approved budget & $\mathrm{P}$ & $\mathrm{P}$ & $\mathrm{P}$ \\
\cline { 2 - 5 } & Amended budget or budget amendments & $\mathrm{P}$ & $\mathrm{P}$ & $\mathrm{P}$ \\
\cline { 2 - 5 } & Budget execution (in year reports) & $\mathrm{P}$ & $\mathrm{P}$ & $\mathrm{P}$ \\
\cline { 2 - 5 } & Year-end report & $\mathrm{P}$ & $\mathrm{P}$ & $\mathrm{P}$ \\
\cline { 2 - 5 } & Multiannual budget outlook & $\mathrm{O}$ & $\mathrm{O}$ & $\mathrm{P}$ \\
\hline Time series & & Some & $\mathrm{P}$ & Some \\
\hline Data download & & Very rare & $\mathrm{P}$ & Some \\
\hline
\end{tabular}

Source: authors.

budget documents that provided no significant additional information to Monitor, with the apparent exception of the draft budget before its approval.

There is no reliable information about the actual users of budget explorers. Anecdotal assessment ranges from very optimistic - in Lanškroun, the number of visitors shows that citizens use budget explorer (Ministry of Interior, 2016) and region Vysočina experienced almost 500 visits within the first month after the launch of its budget explorer (Vysočina, 2013) - to quite pessimistic in Rosice or Kuřim with very low citizens' interest (Ševčíková, 2015). The first budget explorer of all Czech municipalities Rozpočet veřejně mentioned above has more than 2,000 Facebook followers. It is likely that the budget explorers attract users who would never look at budget information otherwise and that budget explorers draw attention to budget information and transparency, which did not exist before.

\section{Conclusions}

Changes in budget transparency in the past decade are tremendous. To a great extent, it is a result of the quick development of ICT and simultaneously growing expectations about its potential or possibilities regarding transparency in the future. Budget explorers as a specific innovation played a crucial role in budget transparency development in the Czech Republic in the past 9 years.

Monitor proved that a budget explorer is a viable form of presentation and especially provision of government budget data. Before its launch, the data were available but in a form that did not allow any meaningful utilisation.

Budget explorers suit the needs of politicians perfectly: They are attractive, easy to implement and up-to-date demonstration of their transparency. It is secondary if this transparency is real, that is, has real added value, or illusionary, as hardly anyone can see the difference.

At the same time, the attempts to be really more transparent, that is, provide previously unavailable information, set new benchmarks. For example, in 2010, nobody thought that a full list of invoices paid by the government including supplier's names, paid amounts and purposes of the payments could be made public. Now, it is becoming a common practice to provide this information either through the budget explorer or as a spreadsheet available on the Internet.

The existence of a variety of budget explorers is a source of new and creative ways of presenting and visualising budget data. At present, we can find the first attempts to link budget data to other information such as public contracts or public procurement information (e.g. cityvizor.cz).

Most of all, budget explorers brought attention to budgets and government management, which is probably much smaller than initially expected but still real. More than 400 news articles in the past 5 years are relevant. This may be quite important whilst taking into account the recent finding of Baekgaard, Serritzlew and Blom $\bigotimes$ Hansen (2016) about the influence of lack of attention on fiscal illusion. 
At the same time, the extent of voluntary information disclosure is very promising and suggests that it may be easier to engage government agencies in various modes of voluntary information disclosure than strengthening of mandatory disclosure and severity of sanctions. Further research should focus on the impact of budget explores on budget management and public participation.

Budget explorers, in general, did not and, as default, could not ensure anyone that the government's management is economic, effective, efficient and corruption free. It is possible to see how much is spent but without information about output or outcome, that is, performance measurement, of these expenditures; the only control that is possible is whether it is in compliance with the approved budget.

Diffusion of budget explorers set up the direction and narrowed the general debate about budget transparency. The focus on the even greater detail of real expenditures is entirely prevalent. Little attention is given to the draft budgets and their political nature. It is getting more common to accompany the draft budget tables with a narrative, but it rarely links the proposed budget to government's priorities. There are no serious attempts to provide citizens budgets even in the biggest cities. Current budget transparency discussion can be summarised as follows: 'as long as we provide a budget explorer, we are transparent, and there is no need to do anything else'.

None of these two drawbacks can be solved miraculously by new technology. They are, even after 25 years of transformation, still missing in the Czech, not only local, government.

\section{Acknowledgements}

This research was carried out with the financial support of the Internal Grant Agency and institutional support of the University of Economics, Prague, No. F1/1/2016 and IP 100040.

\section{REFERENCES}

Bannister, F., \& Connolly, R. (2011). The trouble with transparency: a critical review of openness in e-government. Policy \& Internet, 3(1), 1-30.

Benito, B., \& Bastida, F. (2009). Budget transparency, fiscal performance, and political turnout: An international approach. Public Administration Review, 69(3), 403-417.

Baekgaard, M., Serritzlew, S., \& Blom-Hansen, J. (2016). Causes of Fiscal Illusion: Lack of Information or Lack of Attention?. Public Budgeting \& Finance, 36(2), 26-44.

Bertot, J. C., Jaeger, P. T., \& Grimes, J. M. (2010). Using ICTs to create a culture of transparency: E-government and social media as openness and anti-corruption tools for societies. Government information quarterly, 27(3), 264-271.

Bovens, M. (2007). Analysing and assessing accountability: a conceptual framework1. European law journal, 13(4), 447-468.

Brendlová, E. (2011) Podívejte se on-line: ceny všeho, co platí magistrát. Mladá fronta Dnes 14.12.2011, p. 2.

Cuadrado-Ballesteros, B. et al. (2017). The Role of Media Pressure in Promoting Transparency of Local Government. Transylvanian Review of Administrative Sciences, 13(51), 20-37.Dener, C., \& Min, S. Y. S. (2013). Financial Management Information Systems and Open Budget Data: Do
Governments Report on Where the Money Goes? World Bank Publications. [online]. [cit.2017-10-29]. https://openknowledge.worldbank.org/ bitstream/handle/10986/15897/81332.pdf?sequence=2\&isAllowed=y

Fasora, O. (2012) Fiskální iluze a její klasifikace. In Managing and Modelling of Financial Risks. Ostrava: VŠB-Technical University Ostrava. [online]. [cit.2019-3-3]. https://www.ekf.vsb.cz/export/sites/ekf/rmfr/. content/galerie-dokumentu/2014/sbornik/Fasora.Ondrej.pdf

Frýdek Místek (2017). Dodatek číslo 26 ke smlouvě číslo SWR/95/35 ze dne 22.2.1995. [online]. [cit.2017-06-29]. Available from https://smlouvy.gov. cz/smlouva/893845

Grimmelikhuijsen, S. G., \& Welch, E. W. (2012). Developing and testing a theoretical framework for computer-mediated transparency of local governments. Public administration review, 72(4), 562-571.

Halachmi, A., \& Greiling, D. (2013). Transparency, E-Government, and Accountability. Public Performance \& Management Review, 36(4), 562584 .

Heald, D. (2003). Fiscal transparency: concepts, measurement and UK practice. Public Administration, 81(4), 723-759.

Heald, D. (2012). Why is transparency about public expenditure so elusive?. International Review of Administrative Sciences, 78(1), 30-49. 
Hnátková, M., Křen, M., Procházka, P., \& Skoumalová, H. (2014). The SYN-series corpora of written Czech. In Proceedings of LREC 2014, pages 160-164, Reykjavik, Iceland.

IMF (2017). Fiscal transparency code. [online]. [cit.2017-06-29]. Available from http://www.imf.org/external/np/fad/trans/

Jakubcová, H., \& Paclík, J (2013). Nově Město na Moravě i Třebíč propadly klikacím rozpočtům na webu [online]. [cit.2017-05-17]. Available: http://jihlava.idnes.cz/nove-mesto-i-trebic-propadli-magii-klikacihorozpoctu-na-webu-pth-/jihlava-zpravy.aspx?c=A131016_1988943_ jihlava-zpravy_mkk

Kratochvílová, S. (2014). Nauči elektronický klikací rozpočet obce lépe hospodařit? Moderníobec. 20(8),8.

Michl, A. (2010). Až po uši. Mladá fronta Dnes. 16.11.2010, p. 12.

Michl, A. (2012). 2012, první rozklikávací. [online]. [cit.2017-0629]. Available from http://blog.aktualne.cz/blogy/ales-michl. php?itemid $=15074$

Ministry of Finance (2017). Monitor. [online]. [cit.2017-06-29]. Available from http://monitor.statnipokladna.cz/2017/

Ministry of Interior (2016). Prívětivý úrad 2016: Př́klady dobré praxe. [online]. [cit.2017-06-29]. Available from http://www.mvcr.cz/soubor/ publikace-mvcr-privetivy-urad-obci-iii-typu-2016-priklady-dobre-praxe. aspx

Ministry of Interior (2017). Přivětivý úřad 2017: Přkilady dobré praxe obci s rozšiřrenou působností. [online]. [cit.2017-06-29]. Available from http:// www.mvcr.cz/soubor/privetivy-urad-2017-priklady-dobre-praxe-obciiii-typu.aspx

Nový Jičín (2017). Smlouva o dílo č.V2016-525/OO. [online]. [cit. 2017-0629]. Available from https://smlouvy.gov.cz/smlouva/766025

OECD. (2002). Best Practices for Budget Transparency. [online]. [cit.201705-18]. Available from <http: //www.oecd.org/dataoecd/33/13/1905258. $\mathrm{pdf}>$

Open Budget Partnership (2017). Open Budget Survey. [online]. [cit.201706-29]. Available from http://www.internationalbudget.org/openingbudgets/open-budget-initiative/open-budget-survey/

Oživení (2017). Hodnocení krajů. [online]. [cit.2017-06-29]. Available from http://www.hodnocenikraju.cz/web/

Pikartová, T. (2014). Kraj Vysočina zavedl klikací rozpočet. Co vše umožňuje? Moderní obec. 20(11),13.

Přech, V. (2013). Přehled o rozpočtu mohou mít úředníci i občané. Moderníobec. 19(3), 21
Ramkumar V., \& Shapiro I. (2011). Guide to Transparency in Government Budget Reports: Why are Budget Reports Important, and What Should They Include? [online]. [cit.2015-03-15]. Available from http://www. internationalbudget.org/wp-content/uploads/Guide-to-Transparencyin-Government-Budget-Reports-How-Civil-Society-Can-Use-BudgetReports-for-Research-and-Advocacy-English.pdf

Rozpočet Veřejně (2011). Blog projektu Rozpočet Veřejně [online]. [cit.2017-05-18]. Available from http://blog.rozpocetverejne.cz/2011/05/ vitejte-na-blogu-projektu-rozpocet.html

Rubin, I. (1996). Budgeting for accountability: Municipal budgeting for the 1990s. Public Budgeting \& Finance, 16(2), 112-132.

Rubin, I. (2000). The politics of public budgeting. Chatham.

Ryšavý, I. (2012). "Svobodova« Praha se stává průhlednější. Moderní obec. 18(9), 4

Řezáč, K. (2012). Webový portál pro hodnocení veřejných rozpočtů obcí. Master thesis. Masaryk University. [online]. [cit.2017-06-29]. Available from http://www.diplomovaprace.cz/2012/92/thesis.pdf

Sedmihradská, L. (2015a). Rozpočtový proces obcí. Praha, Wolters Kluwer.

Sedmihradská, L. (2015b). Evaluation of draft budgets: A view of local politicians. In: Špalková, D., Matějová, L. (Ed.). Current Trends in Public Sector Research - Proceedings of the 19th International Conference. Brno: Masarykova Univerzita Brno, 157-162.

Sedmihradská, L., \& Kučera, J. (2016). Open budget data and current praxis in Czech towns. In: Proceedings of the 21th International Conference Theoretical and Practical Aspects of Public Finance 2016. Praha: Oeconomica.

Sedmihradská, L., \& Ždárský, M. (2017). What is the added value of the municipal budget explorers? In: Public Economics and Administration - 12th International Scientific Conference. Ostrava, VŠB - Technická univerzita Ostrava, 2017,

Sičáková-Beblavá, E., Beblavý, M. (2008). Jedenást'statočných: Prípadové štúdie protikorupčných nástrojov na Slovensku. Agentúra na podporu výskumu a vávoja. Bratislava.

Szabo, S. et al. (2016). Linking objective-oriented transparency to political leadership and strategic planning. Transylvanian Review of Administrative Sciences. 12(Special issue), 75-90.

Ševčíková, k. (2015). Za co obec utrácí peníze? Klikací rozpočty lidé ignoruji, tvrdí starostové. [online]. [cit.2017-06-29]. Available from http://brnensky.denik.cz/zpravy_region/za-co-obec-utraci-penizeklikaci-rozpocty-lide-ignoruji-tvrdi-starostove-20151105.html 
Vysočina (2013). Klikací rozpočet Kraje Vysočina hlásí už téměř 500 př́stupů. [online]. [cit.2017-06-29]. Available from https://www. kr-vysocina.cz/klikaci-rozpocet-kraje-vysocina-hlasi-uz-temer-500pristupu/d-4051541

Winter, J. (2013b). Vítězí klikací rozpočet a registr smluv. Moderní obec. 19(12), 32

Winter, J. (2013a). Kam miří elektronické služby měst a obcí. Moderní obec. 19(6), 25 